\title{
Effective Implementation of Urban Agendas through Urban Action Structures (UAS): The Case of the Basque Country
}

\author{
Irati Otamendi-Irizar ${ }^{1, * \mathbb{D}}$, Olatz Grijalba ${ }^{1} \mathbb{D}$, Alba Arias $^{1} \mathbb{D}$, Claudia Pennese $^{2}$ and Rufino Hernández $^{1} \mathbb{D}$ \\ 1 CAVIAR Research Group, Department of Architecture, University of the Basque Country, Plaza Oñati 2, \\ 20018 Donostia-San Sebastián, Spain; olatz.grijalba@ehu.eus (O.G.); albajuncal.arias@ehu.eus (A.A.); \\ rufinojavier.hernandez@ehu.eus (R.H.) \\ 2 RB3, Integrated Urban Innovation, Avda Tolosa 72, 20018 Donostia-San Sebastián, Spain; \\ claudia@rb3innovacion.com \\ * Correspondence: irati.otamendi@ehu.eus
}

check for updates

Citation: Otamendi-Irizar, I.; Grijalba, O.; Arias, A.; Pennese, C.; Hernández, R. Effective

Implementation of Urban Agendas through Urban Action Structures (UAS): The Case of the Basque Country. Sustainability 2021, 13, 6059. https://doi.org/10.3390/su13116059

Academic Editor: Eduardo José Rocha Medeiros

Received: 30 April 2021

Accepted: 26 May 2021

Published: 27 May 2021

Publisher's Note: MDPI stays neutral with regard to jurisdictional claims in published maps and institutional affiliations.

Copyright: (c) 2021 by the authors. Licensee MDPI, Basel, Switzerland. This article is an open access article distributed under the terms and conditions of the Creative Commons Attribution (CC BY) license (https:// creativecommons.org/licenses/by/ $4.0 /)$.

\begin{abstract}
Cities are the main contributors to pollution, resource consumption and social inequalities. Therefore, they should play a key role in the path towards a more sustainable scenario in line with SDGs and different Urban Agendas. However, there are still difficulties in their implementation and citizen can play a central role. This paper presents the Urban Action Structures (UAS), understood as entities with a catalytic capacity with respect to innovative urban policies. Methodologically, firstly, a prospective analysis from regional to international level has been developed, making it possible to identify innovative lines of action in the field of sustainable cities. Secondly, the study has focused on identifying and studying UAS that can make it possible to implement the lines of action previously identified. This paper has shown that there are already social structures that can be understood as UAS, since they implement actions aligned with the priorities of the Urban Agenda for the Basque Country and, therefore, of the SDGs. The research concludes that UAS can play a key role in facilitating the implementation of Urban Agendas. Hence, urban policies should favor the generation of UAS, in order to promote long-term urban development and to foster a more sustainable spatial planning.
\end{abstract}

Keywords: Urban Action Structures (UAS); urban policies; Sustainable Development Goals (SDG); urban agendas; Community-Based Development (CBD)

\section{Introduction}

According to United Nations data, more than 55 percent of the world's population lives in cities and urban areas, and this proportion will grow to 68 percent by 2050 [1]. In this context, the beginning of the 21st century has been characterized by a renewed interest in policies specifically aimed at cities, as these are the primary nuclei of pollution, resource consumption and social inequality. Cities will play a key role in making the effective transformations required to go beyond the current situation. That is, they will be key foci in terms of making development and the well-being of the world's population compatible with the planet's capacity and resources. Contemporary technological-digital, energy-environmental and demographic-social transitions offer an opportunity to change the urban development model and promote social cohesion. Transformation in these areas can constitute the basis of a future built on sustainable development. In this context, urban policy takes on a special role. According to UN-HABITAT, urban policy is a set of coherent decisions, derived from a collaborative deliberative process, that bring together different agents towards a common vision and objectives, which must promote more transformative, long-term, inclusive and resilient urban development [2].

In line with the above, there is commitment by public authorities internationally to implement substantial changes in the urban model. This commitment is materialized through Sustainable Development Goals (SDGs) and the development of international, 
national and local Urban Agendas to enable the implementation of these SDGs at a more local scale [3].

Some authors defend the contribution that Urban Agendas can make in terms of balancing the protection of universal human rights, protection of the environment and economic development [4]. While recognizing the essential need to promote social innovation [5], "the need to move from innovation for economic growth to innovation for sustainable development" should also be highlighted [6] (p. 6).

However, returning to the framework document, the 2030 Agenda for Sustainable Development, it can be stated that difficulties remain in terms of implementation. The 2019 SDG Report [7], after evaluating the impacts obtained, underlined the urgency of enhancing implementation in order to meet the challenges posed by 2030. Going one-step further, the more recent 2020 report envisions that it will be difficult to achieve these global goals by 2030: "One third of the way into our SDG journey, the world is not on track to achieve the global Goals by 2030. Before the COVID-19 outbreak, progress had been uneven, and more focused attention was needed in most areas. The pandemic abruptly disrupted implementation towards many of the SDGs and, in some cases, turned back decades of progress" [8] (p. 3).

The SDGs have received criticisms due to the difficulties involved in quantification, monitoring and implementation $[9,10]$. Certain indicators are qualitative, while monitoring of other areas demands "requires high-quality, timely, and accessible data, often in areas where data are rarely available", among other issues, due to the socio-economic differences between countries [11] (p. 2).

There is a general consensus that the success of the 2030 Agenda demands actions developed at a local level and adapted to local contexts [12]. In this sense, several authors draw attention to a need to improve local leadership capacity [13] and defend the role of local administrations as the main agents of implementation [14].

With respect to local scale actions, it is essential to talk about citizen involvement. Participation and inclusion have been shown to facilitate stakeholder ownership of applied sustainable development strategies [12]. In this context, several works make the case that "citizen science has the potential to contribute to several SDGs" although "limitations exist when measuring the impact that citizen science has made toward SDG progress" [11] (p. 2). Thus, research which proposes self-evaluation of European projects in relation to "citizen science" through the completion of a questionnaire to evaluate their contribution to the SDGs is of interest [15]. It has also been stated, based on experience, that Citizen Observatories (COs) have the potential to contribute to SDGs [16].

In line with the above, it is worth mentioning various proposals center active citizen participation. The annual report of the United Nations Development Program (UNDP) states that People-Centered Development (PCD) places people at the center of development processes as both drivers and beneficiaries [17]. This type of initiative has already been carried out in practice by a variety organizations and cities [18].

Going one step further, Zavratnik et al. [6] (p. 7) use the concept of CommunityCentered Development (CCD). This is an evolution of the PCD approach, "shifting attention from individuals to groups of people, living and collaborating within cities and villages". CCD is based on four principles, of which the third is of particular interest within the framework of this article: "Smart and proactive citizens are the driving force of smart cities and smart villages; capacity and community building, empowerment, and behavioral change are inseparable parts of the development of smart and sustainable solutions, individually and collectively".

However, there are earlier proposals that, with minor terminological differences, also revolve around community-based development. This is the case with CommunityBased Development, which according to Zavratnik et al. [6] can be understood as an umbrella term for approaches accelerating the participation of communities in development processes $[19,20]$. 
In short, all these proposals defend action from a local scale, directed by communities themselves. The debate on the very concept of "community" and its importance has occupied many social science researchers [21,22]. According to Tönnies community is a (Gemeinschaft), a type of association in which natural will predominates. By comparison, society (Gesellschaft) is a type of community formed and conditioned by the rational will. Thus, community can be defined as a group of people who act cooperatively according to common objectives [23]. Other authors understand that community is something that is defined, beyond geography, by relationships, interactions and feelings of joint belonging [6]. In this article, we revisit and reinterpret earlier proposals. We understand community as a group of people who share common objectives-which can be diverse in nature-as well as a feeling of joint belonging, nurtured by their relationships and interactions.

In this context, this paper assumes that a successful sustainable future can be achieved through the effective implementation of urban agendas. Thus, the research hypothesis that an effective way forward derives from addressing the global from the local, in a process in which citizens play a central role. Therefore, we present the concept Urban Action Structures (UAS), which are understood as organized communities that act as motors of local development. These aim to realize transformative actions aligned along the three transitions: technological-digital, energy-environmental and demographic-social. They seek to improve the quality of life for everyone, through the implementation of equitable and inclusive local development processes in balance with the environment.

The purpose of this work is to analyze and define UAS acting as catalysts for innovative urban policies and facilitating the implementation of Urban Agendas. It is based specifically on the Basque Country and the Bultzatu 2050 Urban Agenda [24]. To this end, this research first of all involves a phase of analysis of the international context-which is contrasted with the context of the Basque Country-in order to identify the trends applicable to our context. Afterwards, innovative lines of action are identified through reference cases, defining the innovative action framework for the Basque Country. Finally, pre-existing UAS in the Basque Country are identified and their characterization is addressed, analyzing their fields of action. In this way, the potential of the UAS for the implementation of urban agendas is corroborated.

Following this introduction, the methodology used is presented. Finally, the presentation of results is structured in accordance with the two phases of the methodology.

\section{Materials and Methods}

The methodology applied in this research was structured in three phases, as explained in this section and in Figure 1.

In the first phase, a surveillance and prospective analysis of the current context was carried out at a European and international level. The objective was to establish a global vision of the current context and future projections in the field of transitions to urban sustainability. The approaches with innovative and attractor potential were identified for Europe and the Basque Country. Key themes and projects to be developed over coming years were also defined. The current status and projections for the future were analyzed, taking into account several points or actions: trends, initiatives, UN reports, plans and agendas, projects, open and forthcoming subsidies and financial supports. To achieve this, the most interesting search engines, newsletters, web pages and initiatives were defined at international, national and regional levels. An internal database was generated. Through these tools, the main topics present in the international scene and the main fields (work areas) to be developed and promoted in the Basque Country were defined. The information gathered was systematized through a conceptual map, which was used to assess the coherence of the Basque Urban Agenda Bultzatu 2050 within the current international context and as a basis for undertaking the study of urban action structures. 


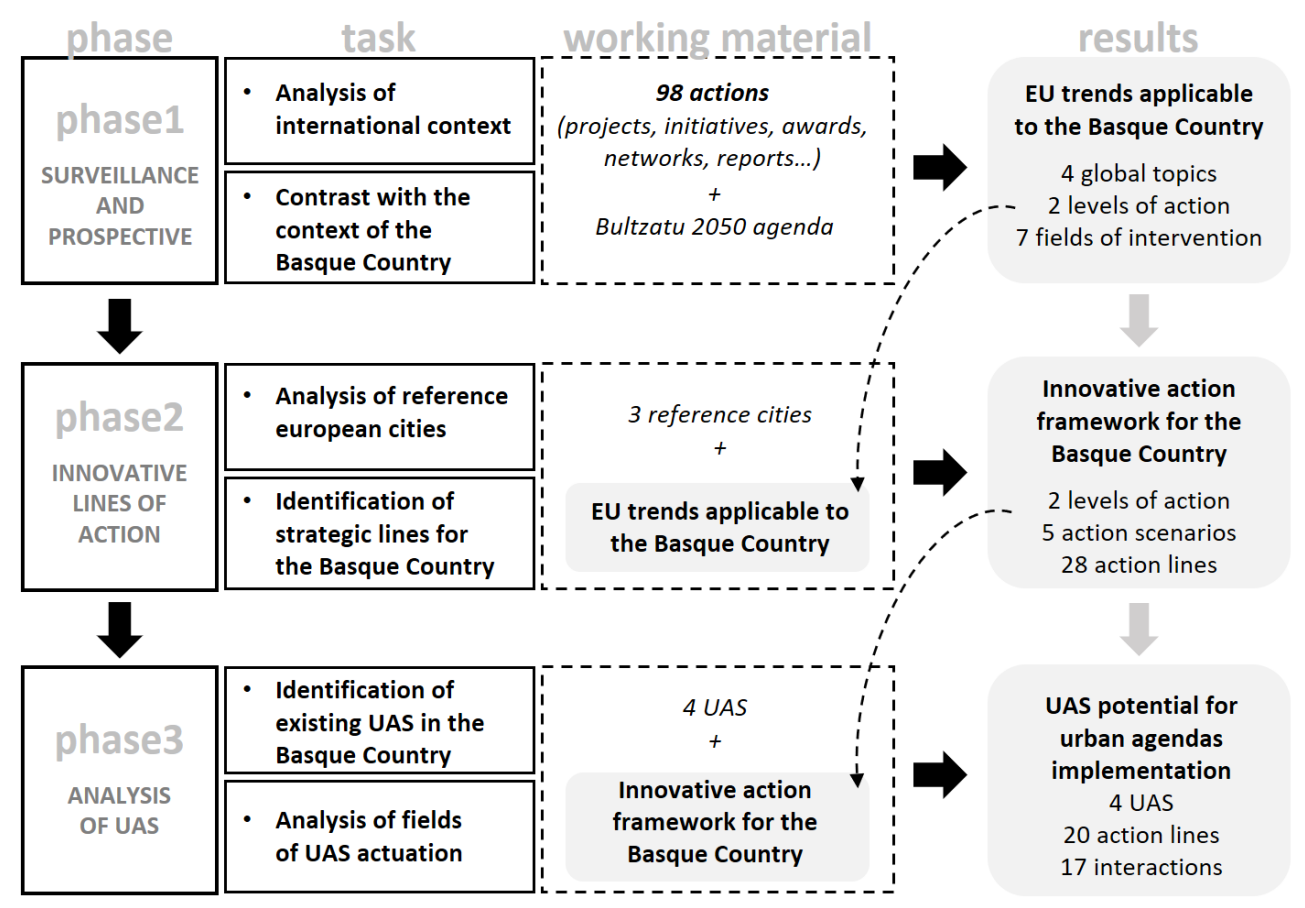

Figure 1. Outline of the methodology applied.

The surveillance process has been carried out on actions related to the themes: smart cities, energy renovation of buildings, energy, urban resilience, nature-based solutions, the human factor, and governance. The study period is from 2014 to the present day. Among all the data analyzed, 95 actions have been selected and thoroughly studied. In order to allow an equitable system of evaluation and enable results to be compared, the analysis process has considered the intervention axis of the 2050 Bultzatu Agenda as the topic for classification. The study has been conducted by counting the frequency with which each topic is objective or main priority of each action (number of times it is repeated out of the total number of actions). It is considered a remarkable and trending topic when is repeated $50 \%$ or more over the total. The results obtained are presented by groups of actions: projects (considered as the practical context) and initiatives, networks, awards, reports, and agendas (considered as the theoretical context). Subsequently, they have been contrasted with the main objectives of the EU and its Horizon Europe framework program. Finally, it has been foresighted the main international trends and the themes that are the most noteworthy to consider them to define new innovative, disruptive, and successful projects. In the second phase, the identification of innovative lines of action applicable to the context of the Basque Country was addressed. To this end, the knowledge derived from the previous phase has been used as a starting point, selecting European cities detected as good practices, which allow for the identification of specific lines of action that may be strategic for the Basque Country. The selection criteria were to choose cities that have been recognized for their commitment to sustainability, are aligned with urban agendas and belong to regions with an outstanding level of innovation. Likewise, urban and demographic characteristics have been taken into account in order to reach references comparable to the reality of the Basque Country. The starting point was a list of the 84 cities that have received outstanding awards in relation to sustainability (European Green Capital Awards, European Green Leaf Awards and European Mobility Award) between 2010 and 2022. After comparing the aforementioned list with the Regional innovation scoreboard 2019 [25], three reference cities have been selected. Through the analysis of these cities, it has been possible to determine a wide range of specific actions that are framed within the previously identified themes that make up the framework of innovative action for the Basque Country. 
Thus, the method in this second phase consisted of identifying the cities considered good practices, drawing up a tree of strategies and actions for each one, and systematizing the above, creating a map grouping the actions according to previously defined themes and global levels.

In the third phase, following on from the process of identifying innovative lines of action in the field of sustainable cities, the study focused on identifying Urban Action Structures (UAS) that can make it possible to implement the lines of action previously identified. In other words, the aim was to identify formulas to implement the goals established by the Urban Agenda, promoting a leading and active role for citizens and other strategic agents, acting from a local scale, as part of a shift orientated around the three key transitions named above.

For this purpose, the reference territory-Basque Country-was investigated to identify active social structures whose fields of action are aligned with the strategic priorities defined by the Urban Agenda for the Basque Country-Bultzatu 2050. This process has been supported by other studies related to the subject, as well as by the analysis of current initiatives in the region allowing the identification of the actors that have been the driving forces behind them. Following the identification of these structures, a similar process of systematization orientated by the lines of action addressed by each of these structures was carried out and by grouping the lines of action of each UAS, its scope of action of each was delimited. This allowed the lines of action addressed by various UAS to be detected, thus establishing shared scopes of action. In this way, it has been corroborated that the pre-existing social structures implement the actions aligned with the Basque Urban Agenda Bultzatu 2050 and that they are coherent with the global strategic themes detected at European level.

\section{Results and Discussion}

\subsection{Innovative Lines of Action in the Context of Urban Agendas}

\subsubsection{The European Contextual Framework}

Following on from the prospective analysis carried out in phase 1 at an European level, four global topics of interest were identified as main current objectives of the European Union. These areas were reinforced by the European Commission in the wake of the COVID 19 health crisis and allocated funding for the period 2021-2027. The four areas are: socio-economic recovery, green and digital transition, energy rehabilitation and low carbon transition. In addition, the results of the surveillance process carried out (see Figure 1), has highlighted the necessity of promoted urban generation in order to make the cities more sustainable and resilient to the climate change. To that end, the importance of the implementation of a sustainable production and consumption should also be underlined; these goals mainly focus on renewable energy and energy efficiency, as well as a digitalization and monitoring processes and natural and waste management. The aim is to make the cities more connected and smarter, efficient and with a local and circular economy. The networks, strategies, initiatives and awards studied have also emphasized that cities should become inclusive and diverse in order to include the citizens in the process of insertion of new sustainable mobility systems, nature-based solutions and cultural and leisure opportunities, which will help to improve the comfort and health of the population. At the same time, all this action topics are supported by the EU main goals for the next few years, and they are include among the priority strategies and main intervention axes proposed by the Urban Agenda Bultzatu 2050 (see Figure 2). 


\begin{tabular}{|c|c|c|c|c|}
\hline \multicolumn{2}{|r|}{ URBAN AGENDA BULTZATU 2050} & \multicolumn{3}{|c|}{ EUROPEAN CONTEXT } \\
\hline PRIORITY STRATEGIES & INTERVENTION AXES & Projects & $\begin{array}{c}\text { Initiatives, } \\
\text { awards, } \\
\text { networks, } \\
\text { reports,... }\end{array}$ & $\begin{array}{c}\text { European } \\
\text { Union } \\
\text { trends }\end{array}$ \\
\hline \multirow{4}{*}{$\begin{array}{l}\text { 1. Housing and basic } \\
\text { facilities }\end{array}$} & Access to housing for all & $3 \%$ & $20 \%$ & $\mathrm{x}$ \\
\hline & Regeneration and rehabilitation of buildings and dwellings & $26 \%$ & $25 \%$ & $x$ \\
\hline & Basic facilities & $6 \%$ & $10 \%$ & \\
\hline & Accessible and high quality environment and public spaces & $12 \%$ & $25 \%$ & \\
\hline \multirow{4}{*}{ 2. Mobility and transport } & Sustainable mobility & $17 \%$ & $45 \%$ & \\
\hline & Intra-urban mobility & $10 \%$ & $45 \%$ & \\
\hline & Inter-urban mobility & $10 \%$ & $35 \%$ & \\
\hline & Multimodal mobility & $12 \%$ & $35 \%$ & \\
\hline \multirow{4}{*}{$\begin{array}{l}\text { 3. Sustainable urban } \\
\text { planning }\end{array}$} & Protection of cultural and natural heritage & $28 \%$ & $55 \%$ & $\mathrm{x}$ \\
\hline & Resilience of the territory and natural heritage & $51 \%$ & $55 \%$ & $\mathrm{x}$ \\
\hline & Sustainable land use & $4 \%$ & $45 \%$ & $\mathrm{x}$ \\
\hline & Spatial equity & $3 \%$ & $30 \%$ & \\
\hline \multirow{4}{*}{ 4. Innovative Cities } & Research, innovation and technology & $61 \%$ & $80 \%$ & $\mathrm{x}$ \\
\hline & Connectivity & $65 \%$ & $60 \%$ & $\mathrm{x}$ \\
\hline & Smart cities & $55 \%$ & $55 \%$ & $\mathrm{x}$ \\
\hline & Non-technological innovation & $12 \%$ & $45 \%$ & $\mathrm{x}$ \\
\hline \multirow{4}{*}{$\begin{array}{l}\text { 5. Economic development } \\
\text { and employment. } \\
\text { Dynamic and competitive } \\
\text { cities }\end{array}$} & Sustainable production and consumption & $68 \%$ & $65 \%$ & $\mathrm{x}$ \\
\hline & Quality employment & $17 \%$ & $45 \%$ & $\mathrm{x}$ \\
\hline & Resilient local economy & $30 \%$ & $60 \%$ & $\mathrm{x}$ \\
\hline & Circular economy & $68 \%$ & $65 \%$ & $\mathrm{x}$ \\
\hline \multirow{4}{*}{$\begin{array}{l}\text { 6. Sustainable and } \\
\text { resilient cities }\end{array}$} & Pollution and environmental quality monitoring & $58 \%$ & $65 \%$ & $\mathrm{x}$ \\
\hline & Climate action & $68 \%$ & $70 \%$ & $\mathrm{x}$ \\
\hline & Natural resources and waste management & $61 \%$ & $65 \%$ & $\mathrm{x}$ \\
\hline & Biodiversity and ecosystems & $28 \%$ & $65 \%$ & \\
\hline \multirow{4}{*}{ 7. Health and well-being } & Accessibility and Universal Coverage to the healthcare system & $1 \%$ & $15 \%$ & \\
\hline & Equitable and quality healthcare & $1 \%$ & $15 \%$ & \\
\hline & Promoting healthy lifestyle and leisure habits & $4 \%$ & $25 \%$ & \\
\hline & Health innovation and research & $3 \%$ & $40 \%$ & $\mathrm{x}$ \\
\hline \multirow{4}{*}{$\begin{array}{l}\text { 8. Diverse and inclusive } \\
\text { cities }\end{array}$} & Social cohesion & $39 \%$ & $45 \%$ & $\mathrm{x}$ \\
\hline & Intergenerational equality by functional diversity and origin & $14 \%$ & $40 \%$ & $\mathrm{x}$ \\
\hline & Equitable and inclusive education and trainings & $14 \%$ & $55 \%$ & $\mathrm{x}$ \\
\hline & Cultural and leisure opportunities for all & $7 \%$ & $40 \%$ & $\mathrm{x}$ \\
\hline
\end{tabular}

Figure 2. Percentage of repetition of each intervention axes of Bultzatu Agenda in each of the actions analyses during the surveillance process. Detection of the main access promoted by EU as main objectives to develop during the next few years.

Besides, taking into account the observations of the surveillance process and the main trends promoted by EU, it has been foresighted, as a combination of the results obtained before, that the most interesting fields of intervention over coming decades in the Basque Country will include the following:

1. At an urban level (district-region): the implementation of the NBS (Nature-Based Solution), efficient sustainable mobility, the promotion of a local circular economy and urban regeneration.

2. At the building level: the promotion of smart buildings, use of renewable energies and building rehabilitation.

Both at an urban and building level, it is believed that it is important to take into account the human factor (citizen participation, social and cultural inclusion, gender equality, comfort and health) as well as the use of ICTs in order to generate livable spaces and improve energy, water and waste management efficiency by implementing digitization and data management processes (see Figure 3). 


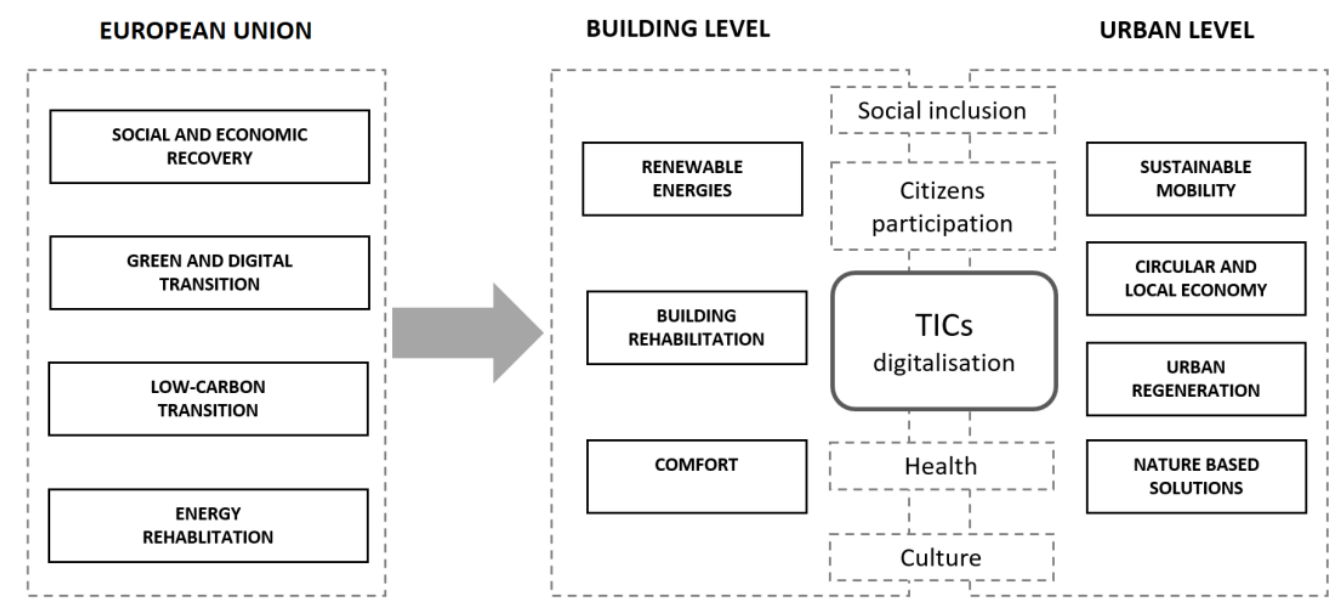

Figure 3. Strategic themes to work on according to level of action.

\subsubsection{Identification of Innovative Lines of Action and Their Linkages}

In phase 2, the starting point was the selection of three European cities detected as good practices, which allow the identification of specific lines of action that could be strategic for the Basque Country: Vienna (Austria), Bologna (Italy) and Lahti (Finland).

As explained above, based on the work carried out in phase 1, in addition to considering urban and demographic characteristics, the selection criteria respond to the recognition that these cities have received for their commitment to sustainability and to the level of innovation that the region to which each city belongs presents according to the Regional Innovation Scoreboard [hereinafter RIS].

From an urban point of view, Bologna is a historic and dynamic city with a surface area of $140.9 \mathrm{~km}^{2}$ and a population of around 400,000 inhabitants; Vienna is a much larger city $\left(414.6 \mathrm{~km}^{2}\right)$ with a population of over 1.8 million inhabitants and is representative of its imperial character; Lahti, a Finnish city with prominent industrial origins, is characterized by its regeneration process. It is $135 \mathrm{~km}^{2}$ in size, has less than 120,000 inhabitants and, although it has a higher-density area, it is complemented by lower-density urban areas, which are more representative of the Nordic countries.

The city of Bologna, in terms of its level of innovation, is at the same level as the Basque Country, being considered at the "Moderate+" level. Additionally, in 2009 it was already considered as "the most sustainable city in Italy" [26] (p. 244) and, in 2011, received the "European Mobility Week" [EMW] Award. In 2017, Bologna was awarded the Civitas award (Bold Measure Award category) for adopting a daring and innovative approach in order to promote environmentally friendly transport modes, rewarding the positive behaviors of citizens by giving discounts and prizes every time they complete a sustainable trip.

Austria is considered "strong+" in terms of innovative capacity and the city of Vienna has received several awards related to sustainability: was ranked first for ten consecutive years (2009-2019) in the Quality of Living city ranking [27]; in 2020, it was awarded the Unesco Smart City award for its "innovative, intelligent, connected and decidedly sustainable" housing policy and was ranked first among Greenest Cities in the World, underlining its strength in the mobility segment.

Lahti is the Finnish city that has won the Green Capital Award in 2021, after being a finalist in 2019 and 2020. As the commission announced, Lahti is particularly strong not only in the fields of air quality, waste, green growth and eco-innovation, but also in governance. The city already established an air quality plan in 1997, which has led to a significant drop in emissions since then. It highlights the mechanism of involving local businesses in air quality monitoring. The central theme and vision for Lahti's 2018 city strategy is "Bold Environmental City" gathering multiple programs and plans focused on 
smart, clean and circular economy, mobility, environment, energy, urban regeneration and citizen science.

Based on the study of the urban strategies and policies of these three cities, a crossanalysis of the identified lines of action has been undertaken. To this end, based on the lessons learned from the prospective analysis, the lines of action at the two identified global levels of action have been systematized by means of a conceptual map. In this way, five scenarios for action have been identified (see Figure 4). At an urban level, the lines of action focused on mobility and public spaces, while at the building level, they took into account housing, facilities, and the considerable stock of industrial facilities in the Basque Country.

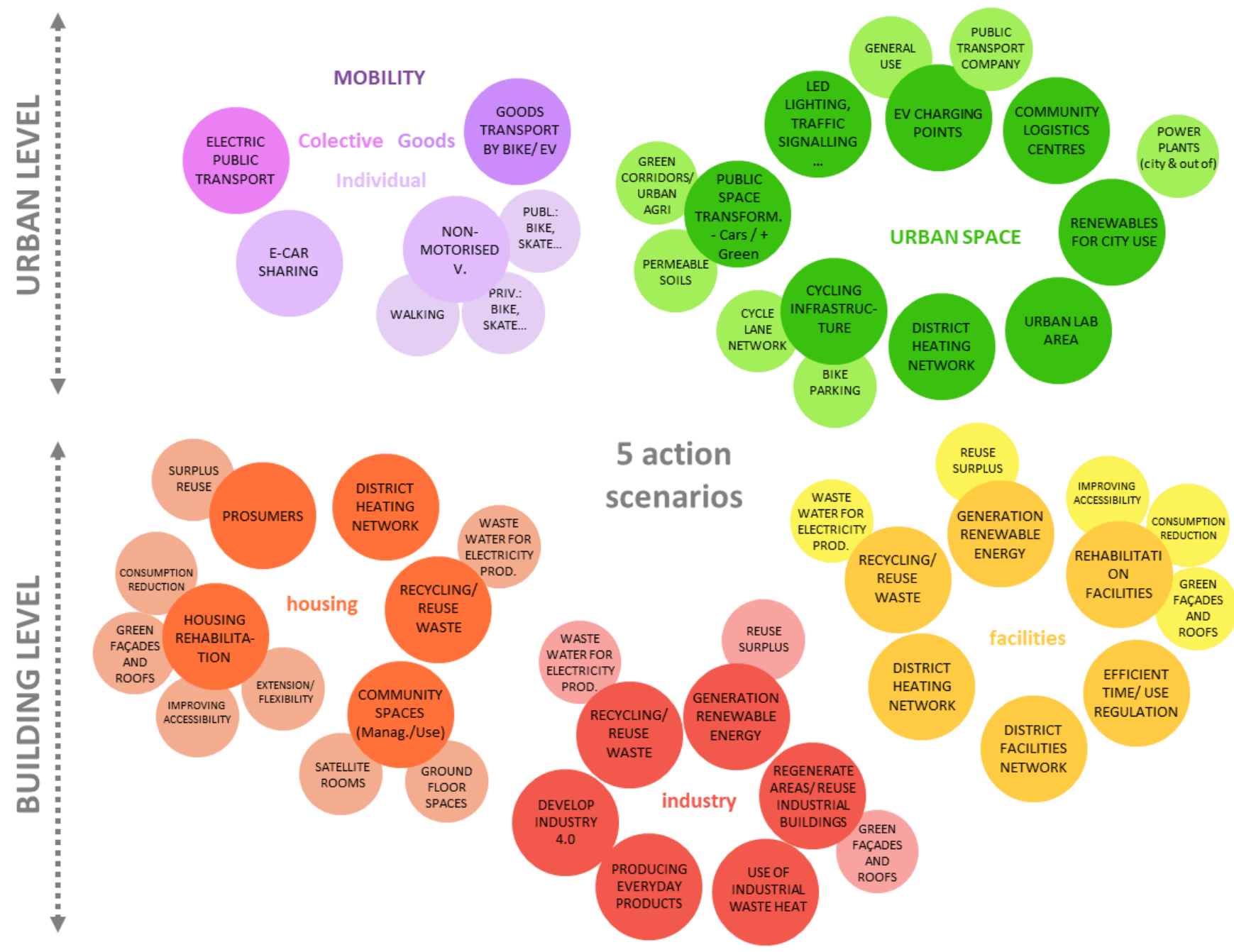

Figure 4. Map identifying strategic action lines.

Carrying out a reading that goes beyond each of the lines of action addressed in the five scenarios, the exercise conducted through this map made it possible to identify the linkage between these action lines and the seven strategic themes identified in phase 1 , covering simultaneously and transversally the two levels of action (see Table 1). 
Table 1. Linkages between the action lines and the 7 strategic themes of phase 1.

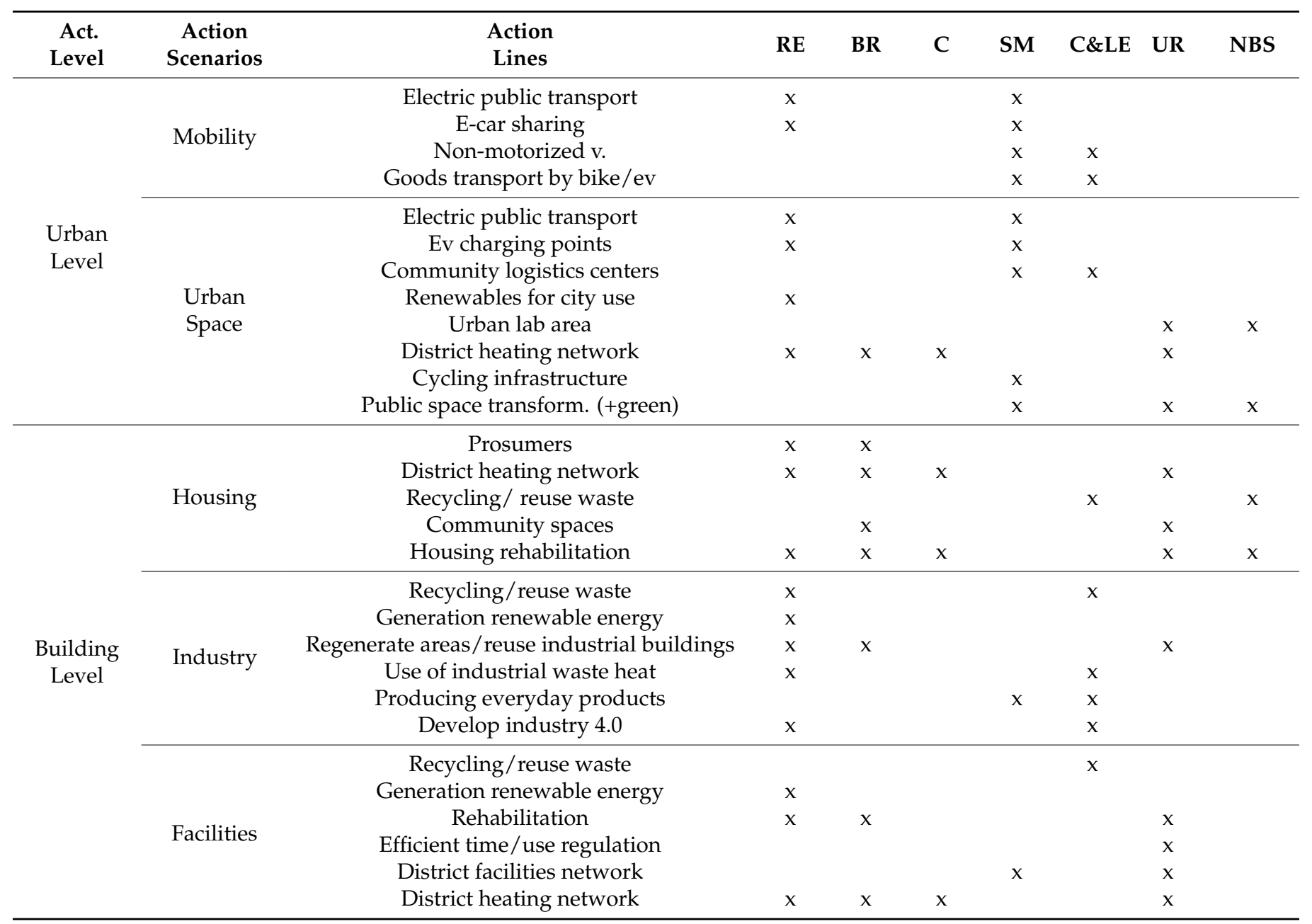

The strategic theme with the greatest presence in these lines of action is Renewable Energies, as $59 \%$ of the action lines are related to this field. It can be considered as a crosscutting theme that is present in the different action scenarios. Likewise, the lines linked to Mobility (38\%), which, reasonably enough, is more closely linked to the urban level scenarios, are also highly present. The next strategic themes, in terms of presence among the lines identified, are building rehabilitation (28\%) and Circular and local economy (31\%). Finally, the two themes that appear with less intensity are Comfort and NBS (14\%).

These results make it possible to define some of the guidelines for urban policies to be implemented as a priority in the territory in question, as set out below.

In the field of renewable energies, one of the main lines of action should address the promotion of self-production. This can generate a change in the energy distribution model and, specifically, a shift towards decentralized production where consumers become prosumers. This can be addressed at the building level, promoting generation facilities in all types of buildings (housing, industry, facilities), as well as at the urban level. Similarly, from an energy efficiency point of view, there is a need to develop comprehensive management models which take into account the different uses and users of the city and their compatibility and complementarity.

The energy theme is directly linked to another strategic theme: sustainable mobility. Thus, in the field of mobility, important transformations towards the sustainability of cities often revolve around reducing the need for physical mobility and promoting electric and non-motorized means of transport. In this context, the main objective is to promote compact cities, where local actions at a district or neighborhood level are essential. The 
second objective, linked to the promotion of electric and non-motorized means of transport, implies a commitment to infrastructure that sustains and supports these alternatives, and which requires transformations in the urban environment. Thus, in addition to the need to reinforce transport networks in cities and at a territorial level, it is essential to create a network of specific infrastructures, including bike racks, charging points for electric vehicles and sharing services, etc. It is noteworthy that the promotion of these specific infrastructures can be stimulated at a local level, which also contributes to the transformation of the urban environment by creating local linkages.

In addition, the achievement of the objectives described above necessarily requires a firm commitment to urban regeneration and the rehabilitation of buildings. In relation to these two strategic issues, it should be noted that any action must start from the premise of sustainable land use, prioritizing the reuse of disused spaces and buildings. In Basque Country specifically, the regeneration of industrial areas and the repurposing of disused industrial buildings should be considered a strategic priority. The rehabilitation of the existing building stock is also to be considered a priority, and take into account the principles of energy efficiency as well as other criteria (accessibility, flexibility, diversification of types, etc.). However, rehabilitation actions in the existing housing stock are understood as strategic response towards making the transitions necessary to adopt an energy model based on self-production, as well as to promote compact cities (in line with short-distance model) and local regeneration, through action in community spaces. This can include, for example, repurposing the often-underused non-residential premises located on the ground floor of residential buildings. Finally, the concepts of comfort, Circular and Local Economy and NBS must be implicitly present when addressing any of the above strategies.

In this context, the cross-cutting themes identified in phase 1 of the research should be highlighted: digitalization, social inclusion, citizen participation, health and culture. The crucial role of digitization in advancing along the aforementioned lines of action is evident. Digital technology should be integrated in all areas of action, facilitating the management of real data. These data can define the needs for which responses are demanded. In other words, technology should be used at the service of people, combining technological innovation with social innovation and facilitating the role of citizens as the main actor. To this end, citizen participation must be a recurrent tool that, through co-creation processes, allows for the construction of a more sustainable future based on the needs of local citizens. Finally, both social inclusion and health and culture are cross-cutting themes that should filter all urban policies.

\subsubsection{Case Study: Basque Country and the Bultzatu 2050 Urban Agenda}

As indicted in the introduction, the geographic scope of reference for this research is the Basque Country. The Urban Agenda for the Basque Country-Bultzatu 2050, is located in this context. The document contains proposals for the Basque Country, "one of the most heavily urbanized European regions" which houses "the second highest population density in Spain, after the Community of Madrid" [24] (p. 4). The Agenda, which was framed in accordance with various international, national and regional planning instruments (see Table 2) aims to "to ensure that we have inclusive, safe, resilient and sustainable towns and cities in which nobody anywhere is left behind". To this end, the document addresses 8 strategic priorities, centered on 31 action areas and 105 lines of action. It also includes " 5 cross-cutting aspects of these priorities, related to multi-level governance of the agenda, gender mainstreaming, the comprehensiveness of the actions, the land use focus and the commitment to monitoring and assessment" [24]. 
Table 2. Framework of the Urban Agenda for the Basque Country-Bultzatu 2050 [24].

\begin{tabular}{|c|c|c|}
\hline $\begin{array}{l}\text { Broad Reference } \\
\text { Framework }\end{array}$ & $\begin{array}{l}\text { Basque Reference } \\
\text { Framework }\end{array}$ & $\begin{array}{c}\text { Framework for Policy } \\
\text { Consistency }\end{array}$ \\
\hline $\begin{array}{l}2030 \text { Agenda } \\
\text { New Urban Agenda } \\
\text { Urban Agenda for the EU } \\
\text { Urban Agenda for Spain } \\
\text { Other instruments: } \\
\text { - Covenant of Mayors } \\
\text { - Chefchauen Declaration }\end{array}$ & $\begin{array}{l}\text { Land Use Planning Guidelines } \\
\text { Basque Country } 2030 \text { Agenda } \\
\text { Basque Declaration } \\
\text { Udalsarea } 2030 \\
\text { Klima } 2050\end{array}$ & $\begin{array}{l}\text { Economy and innovation: } \\
\text { - } \quad 10 \text { plans and strategies } \\
\text { Social inclusion and resilience: } \\
\text { - } \quad 16 \text { plans and strategies } \\
\text { Environmental sustainability: } \\
\text { - } \quad 11 \text { plans and strategies } \\
\text { Governance: } \\
\text { - } 2 \text { initiatives }\end{array}$ \\
\hline
\end{tabular}

The general objective is the implementation of the Urban Agenda for the Basque Country-Bultzatu 2050. The lines of action extracted from the process of systematization described above were compared with the axes of intervention and lines of action set out in this document. This was a strategic step aimed at assessing the coherence and structure of implementation mechanisms at the local level.

The primary result of the exercise described above was that a high degree of consistency was detected. It can be stated that practically all lines of action align, directly or indirectly, with the axes of intervention and the lines of action of Bultzatu2050.

Practically, all the lines of action included in the axes "5.1. Promoting the right to housing and basic facilities", "5.2. Cities on the move: for a new type of mobility", "5.6. Sustainable and resilient cities" and "5.8. Diversity and inclusion as our hallmark" are represented. Similarly, the lines of action identified also coincide with a number of those included in Bultzatu2050, including: "5.3.1. Protecting cultural and natural heritage", "5.3.2. Resilience of the land and natural heritage", "5.4.4. Non-technological innovation", "5.5.3. Resilient local economy" and "5.7.3. Promoting healthy lifestyles and leisure activities".

\subsection{The Potential for UAS in the Implementation of Existing Agendas}

Having obtained the results described in the first phase, study focused on laying the bases for useful knowledge to define UAS capable of acting as local instruments for the implementation of urban agendas, applying the most innovative and viable lines of action in the reference territory. For this reason, we proceeded to identify and analyze existing active structures that can be drivers of the desired urban management and transformation.

\subsubsection{Study of Existing Structures}

In the reference territory there is a strong and consolidated network of associations related, among other aspects, to environmental and social issues from different approaches, which, since the 1960s, has been weaving cooperation networks. We are referring in particular to environmental, ecologist, eco-feminist and cultural collectives which, through their activism, propose structural changes in the system and, therefore, in the city and the territory.

Most of these agents are currently organized in different networks related to alternative and solidarity economy and social intervention. They bring together associations and cooperatives working for local development from the aforementioned approaches.

In order to better identify those potential structures that, within the aforementioned network, can play an active role in the implementation of the Basque Urban Agenda Bultzatu 2050 in terms of urban issues, specific selection criteria have been applied:

- The level of consolidation of the social structure on which they are based.

- The linkage of the community with a specific place within the reference territory. 
- The link with the strategic axes set out in the Urban Agenda for the Basque CountryBultzatu 2050.

- The greater potential to actively support the changes demanded by the three transitions. Thus, in the reference territory four social structures have been identified, which can function independently or as a coordinated whole:

1. Local energy communities (LECs): These structures are to be considered key to an energy-environmental transition. At the European level, LECs have acquired a significant role in a context where there is a commitment to placing citizens at the center of a new democratic, decentralized energy model based on renewable energies. In this context, there already exists—on the European level—a significant network of Energy Communities that have promoted multiple initiatives, thus weaving a significant base of learning [28]. This type of structure is characterized, as is the case in many European LECs, by the way in which they, being prosumer, play an active role in the renewable energy cycle. Thus, they commonly engage in fields of action that encompass, in addition to energy production, the promotion of activities that seek to save energy by promoting electric mobility and energy rehabilitation. Similarly, the reinvestment of profits in local projects to improve the urban environment and contribute to local sustainable development is commonplace, so the activity of these structures goes beyond the field of energy.

In the Basque Country, although there is some movement in this area, the presence of these initiatives is still limited. Goiener [29], a cooperative project for the generation and consumption of renewable energy, is noteworthy. It was created with the aim of achieving energy sovereignty and has established a considerable support base [26]. It is worth mentioning other initiatives of a more local nature, including the Lasierra Local Energy Community [30] and the company Ekiola Energia Sustapenak, born of a collaboration between the Basque Energy Agency and Krean for the promotion of sustainable energy cooperatives. This has already taken some initial steps in two Gipuzkoan municipalities. Local government administrations have become actors in the control of local power generation facilities [31]. Furthermore, at provincial level (Gipuzkoa), the Administration is promoting this type of Community in eight counties (for a total of 81 municipalities), six of which have an energy plan already drawn up and two are in the development phase. In view of these impulses at a macro level, LEC are being set up in different municipalities. In total, nine initiatives are currently registered in the Basque Country as a whole (some of them at an incipient stage), in addition to the two in the neighboring Community of Navarre. All of these initiatives are based in a specific context, normally a small municipality or neighborhood. In addition to these initiatives, there are another two recently promoted by the Basque Government itself in two vulnerable neighborhoods, where a process of energy rehabilitation of residential buildings is being carried out. In these cases, the creation of a LEC would result in the local development of each neighborhood and in the improvement of the quality of life of its population.

2. Collaborative housing structures: These structures are considered interesting in the process of generating new housing models aimed at rethinking the current housing stock in typological terms and as an independent, diversified and inclusive life model. In addition, they constitute an answer to questions around active aging, youth independence and intergenerational relations. They actively contribute to the democratization of housing.

In the reference territory, different senior, youth and intergenerational collectives are currently promoting this model of coexistence. These collectives are already networked with other neighboring provinces to promote the model throughout Spain and to exchange knowledge and experiences [32].

Currently, there is a network [33] made up of a total of 19 associations that are at different levels of development of the project. This network is made up of 19 associations, seven in the Basque Country, 10 in Navarre and two in the nearby 
province of La Rioja. There are other associations that have just been set up and which, being in their initial phase, have not yet joined the network. These are innovative projects to which the public authorities have so far failed to respond, requiring a major change in urban development and housing policy. For this reason, all the currently active cases have been progressing with their projects for years, obtaining partial achievements that, to date, have not materialized in implemented projects. These structures are often able to exceed their own scopes of action and address aspects related to all three transitions. In addition, a self-aware, connected and networked social fabric is seen as an opportunity that facilitates the generation of UAS.

3. Agri-food structures: These are more specific structures focused on the production and/or distribution of local agri-food products. They bring together diverse elements including the circular economy, production and self-consumption of renewable energies and sustainable land use, including a model of mobility based on "Kilometer 0 " logic.

Additionally, in this case, there are interesting antecedents in the reference territory that may constitute fertile ground for a wider implementation of more ambitions structures aimed at generating integrated UAS. This pioneering experience is ripe for expansion in a context in which responsible consumption cooperatives are expanding and consolidating throughout the Basque Country. These could become key promoters of agri-food strategies and/or other related projects.

Since the end of the 1990s, the so-called Agro-villages have been promoted. These are large plots of land that have been prepared for urban agricultural use, normally in public ownership. They usually generate a community of citizens who are responsible for the exploitation of individual vegetable gardens, promoting a community process of local and responsible consumption. There are currently nine agro-villages concentrated in the province of Gipuzkoa [34].

In addition to these pioneering initiatives, more recently, in many municipalities in the Basque Country, the local administration has promoted the creation of more diffuse urban vegetable gardens in the urban fabric which, nevertheless, encourage responsible production and consumption. In this scenario, for example, the municipality of Vitoria Gasteiz stands out, where there are currently 54 public ecological vegetable gardens on municipal land or related to cultural or educational facilities. This important network is the starting point for a pioneering initiative promoted by the city council, which has culminated in the definition of an Agri-Food Strategy that aims for self-sufficiency [35].

4. Urban regeneration structures: These structures have more global ambitions as they bring together a set of issues around the strategic importance that the urban architectural fabric has on means to achieving all three transitions. International, European, state and regional policies highlight, through their respective Urban Agendas, the strategic importance of working in existing cities. Endless growth needs to be abandoned as part of as a basic strategy to achieve balance with the environment, socio-economic equity and equality and social cohesion. Innovative technologies and digitization processes, including the central and ongoing role of citizens as the leading agent of change, and a comprehensive approach as a priority strategy, will be key to achieving results in this area.

Urban Rehabilitation Societies (URS) have a historic presence in the Basque Country. These were promoted in 1983 by the "Decree 278/1983, on the Rehabilitation of the Built Urban Heritage" and there are currently 22 URSs. They have very different characteristics; however, all of them provide different degrees of local support at a neighborhood level. The study conducted by Grijalba et al. [36] showed that they have been one of the determining factors of the implementation of the Rehabilitation policies y que more integrated approaches are considerably greater in those municipalities in which the companies are operating. On occasions, this includes the management of building rehabilitation processes. This situation has recently 
evolved through the creation of the Opengela project, which seeks to extend urban regeneration in the Basque Country using a novel instrument that consists of "the creation of neighborhood offices that act as central desks to serve local residents" [37]. There are currently four operational Opengelas that collaborate with each other to generate a territorial network for the exchange of knowledge. Over the next 3 years, the creation of 36 Opengelas in other neighborhoods of the reference territory is planned, with the aim of progressively adding them to the aforementioned network. However, these are institutional entities which, currently, execute up-down processes in which local citizens are not central active subjects with decision-making power and management autonomy. Beyond these limitations, these antecedents represent an opportunity to create structures that could, horizontally and with the involvement of local communities, apply the principles defined in regional guidelines locally and concretely.

\subsubsection{Fields of UAS Actuation}

Following on from the identification of existing structures, the related UAS which can act as drivers of a set of lines of action to be implemented independently or together were defined. The results of this process are systematized in Figure 3.

To this end, for each action scenario, the lines of action already implemented [x] by the UAS identified and those that can be considered potential lines of action [y] for each of them, i.e., those that could be implemented, were analyzed. This analysis has been systematized in Table 3, which, in addition to presenting these results, makes it possible to visualize and assess the potential for interaction between the different UAS to achieve a high capacity for impact on the path towards the effective implementation of the urban agendas and responding to the three transitions in an integrated manner.

Table 3. Actuation fields and lines of different UAS.

\begin{tabular}{|c|c|c|c|c|c|c|}
\hline Act. Level & $\begin{array}{c}\text { Action } \\
\text { Scenarios }\end{array}$ & Action Lines & $\begin{array}{l}\text { Local } \\
\text { Energy } \\
\text { Community }\end{array}$ & $\begin{array}{l}\text { Urban Re- } \\
\text { generation } \\
\text { Structure }\end{array}$ & $\begin{array}{l}\text { Agri-Food } \\
\text { Structure }\end{array}$ & $\begin{array}{l}\text { Collaborative } \\
\text { Housing } \\
\text { Structure }\end{array}$ \\
\hline \multirow{12}{*}{ Urban Level } & \multirow{4}{*}{ Mobility } & Electric public transport & \multirow{4}{*}{$\begin{array}{l}x \\
y\end{array}$} & $\mathrm{y}$ & & \multirow{4}{*}{$\begin{array}{l}\mathrm{y} \\
\mathrm{x}\end{array}$} \\
\hline & & E-car sharing & & $\mathrm{y}$ & & \\
\hline & & Non-motorized v. & & $x$ & & \\
\hline & & Goods transport by bike/ ev & & $\mathrm{y}$ & $x$ & \\
\hline & \multirow{8}{*}{$\begin{array}{l}\text { Urban } \\
\text { space }\end{array}$} & Electric public transport & \multirow{3}{*}{$\mathrm{x}$} & $x$ & & \multirow{4}{*}{$\mathrm{y}$} \\
\hline & & Ev charging points & & $\mathrm{y}$ & & \\
\hline & & Community logistics centers & & $\mathrm{y}$ & $x$ & \\
\hline & & Renewables for city use & $x$ & $x$ & & \\
\hline & & Urban lab area & \multirow{3}{*}{$\mathrm{y}$} & $\mathrm{y}$ & & $\mathrm{y}$ \\
\hline & & District heating network & & $x$ & & $x$ \\
\hline & & Cycling infrastructure & & $x$ & & $\mathrm{y}$ \\
\hline & & Public space transform. (+green) & $\mathrm{y}$ & $x$ & $x$ & $\mathrm{y}$ \\
\hline \multirow{15}{*}{ Building Level } & \multirow{5}{*}{ Housing } & Prosumers & $x$ & $\mathrm{y}$ & \multirow[t]{2}{*}{$\mathrm{y}$} & $x$ \\
\hline & & District heating network & $\mathrm{y}$ & $x$ & & $x$ \\
\hline & & Recycling/ reuse waste & $\mathrm{y}$ & $\mathrm{y}$ & $x$ & $\mathrm{y}$ \\
\hline & & Community spaces & $\mathrm{y}$ & $\mathrm{y}$ & $x$ & $x$ \\
\hline & & Housing rehabilitation & $\mathrm{y}$ & $x$ & & $\mathrm{y}$ \\
\hline & \multirow{4}{*}{ Industry } & Recycling/ reuse waste & & $\mathrm{y}$ & & \multirow{4}{*}{$\mathrm{y}$} \\
\hline & & Generation renewable energy & $\mathrm{y}$ & $\mathrm{y}$ & & \\
\hline & & $\begin{array}{c}\text { Regenerate areas / reuse industrial } \\
\text { buildings }\end{array}$ & & $\mathrm{y}$ & & \\
\hline & & $\begin{array}{c}\text { Use of industrial waste heat } \\
\text { Producing everyday products } \\
\text { Develop industry } 4.0\end{array}$ & & $\mathrm{y}$ & & \\
\hline & \multirow{6}{*}{ Facilities } & Recycling/ reuse waste & & $\mathrm{y}$ & & \multirow{6}{*}{$\mathrm{y}$} \\
\hline & & Generation renewable energy & $x$ & $x$ & & \\
\hline & & Rehabilitation & $\mathrm{y}$ & $\mathrm{y}$ & $\mathrm{y}$ & \\
\hline & & Efficient time/ use regulation & & $\mathrm{y}$ & & \\
\hline & & District facilities network & & $\mathrm{y}$ & & \\
\hline & & District heating network & & $\mathrm{y}$ & & \\
\hline
\end{tabular}


Sixteen of the 29 action lines identified in phase 2 (55\% of the total) are already being implemented today. Among the implemented action lines, nine correspond to the Urban Regeneration Structure (URS) and five to each of the other identified UASs. It should be noted that the same lines are repeated in more than one structure.

In order to evaluate the structures with the greatest potential for innovation and development in the reference territory, the relative and total percentages of implemented and potential lines were analyzed. The result shows that the line with the greatest potential is the URS, with $31 \%$ of implemented lines and $62 \%$ of potential lines, with an overall potential of $93 \%$. Its overall potential over all the lines of action is $93 \%$, which defines it as an important opportunity for innovation and evolution over time. Its overall potential over all the lines of action is 93\%. The Local Energy Community (LEC) and the Collaborative Housing Structure (CHS) follow with an overall potential corresponding to $48 \%$ of the total. In both structures, $17 \%$ of the lines are already implemented and both have the potential to implement a further $31 \%$, even if in different areas. From this analysis, the Agri-Food Structure (AFS) has the lowest potential, only $24 \%$, implementing $17 \%$ of the lines and with a very low development rate of only $(7 \%)$.

The fact that some lines of action are currently being implemented or could be implemented by several UASs points to opportunities for collaboration between different structures. It has been found that 8 of the 29 lines (27.5\%) are already implemented by two structures. Considering these shared lines, URS and CHS implement and share the largest number of lines with other structures (six and five respectively) and the LECs and the AFS are only involved in three lines. On the other hand, among the eight lines implemented by two UAS, three have the potential for two other UAS and three for one more. Finally, four of the lines that are implemented by a single UAS are potential for two other UAS, and one more line is presented as potential for three other UAS. Thus, the lines shared by most UAS refer mainly to Renewable Energy, Urban Regeneration and Sustainable Mobility. Themes such as NBS and Building Rehabilitation currently have a lower level of implementation.

From all these data, it can be deduced that the structure with the greatest potential is the URS, not only because of the higher level of lines already implemented, but also because of the high percentage of potential lines, which makes it a structure that can play a strategic role in the future on the road to the three transitions. A significant impact potential is also recognized for the LEC and the CHS. However, it has to be considered that the CHS works especially at the building level and not at the whole or neighborhood/district level. In addition, there are currently many regulatory barriers that limit the effective implementation of this housing model. On the other hand, with regard to the LECs, there is a very favorable European and national framework from the point of view of priority action strategies and the legal reference framework itself. This aspect amplifies their potential. In addition, LECs have been identified as strategic structures, as they are able to function as drivers of other actions. In this sense, in view of the actions that are already being promoted in European projects, it can be affirmed that the LECs have the capacity to bring together different lines of action beyond those specifically limited to energy and, therefore, can promote an integral process of transformation of urban environments. Furthermore, as seen in phase 2, the issue of renewable energies and the shift towards decentralized production is strategic and LECs are essential for this. It can, therefore, be argued that these structures can be connected and form part of a more complex system.

With regard to the ability of collaboration between different UAS, it has been shown that actual and potential interactions already exist with different possible combinations that could be enhanced by implementing the potential lines and doing so in a synergistic way. Likewise, the URS and the CHS have the greatest potential for collaboration. This collaboration could be carried out through different forms of association or grouping of these structures, eventually forming a new UAS between them. Thus, considering that the scale of action, in accordance with the morphological and socio-demographic characteristics of the reference territory, is the neighborhood or district, it should be noted that in a city 
there could be several associations or groupings of UAS and, therefore, a network of UAS would be woven at the territorial level.

\section{Conclusions}

Despite international commitment towards the construction of a future scenario based on SDGs and the development of urban agendas at different scales for their achievement, obstacles to implementation are still considerable. In this article, an exercise was carried out to address this reality, which is also evident in the case of the Urban Agenda for the Basque Country-Bultzatu 2050.

There is broad consensus that a transition to sustainability must be carried out through local actions adapted to specific contexts, and that citizens must play a central role in this process. In this article, in accordance with various proposals that put people, as beneficiaries and agents, at the center of the processes, the importance of the concept of community was underlined. Community was understood as a group of people who share common objectives - which can be different and diverse in nature-as well as a sense of belonging together, fueled by their relationships and interactions.

In this context, UAS, understood as organized communities acting as motors of local development, were presented. The objective of these collective actors is the execution of transformative actions aligned towards achieving the three transitions, seeking to improve the quality of life for everyone. Thus, in this article UAS are presented as entities with a catalytic capacity with respect to innovative urban policies. They can play a key role in facilitating the implementation of Urban Agendas.

Going one step further, this research has shown that there are already social structures that can be understood as UAS, since they implement actions aligned with the objectives and priorities of the Urban Agenda for the Basque Country-Bultzatu 2050 and, therefore, of the SDGs. Similarly, the study made it possible to corroborate that different UAS partially share fields of action and address common lines of action. Therefore, urban policies should favor the generation of urban structures, in order to promote long-term urban development that is more transformative, inclusive and resilient.

In this context, it has been seen that the UAS with the greatest potential are the URS and the LEC. Both, in addition to their combined capacity for action and impact, have the potential to boost other UAS, even incorporating them into their own structure and fields of action. Thanks to these impulses and interactions, the capacity to promote a comprehensive process of transformation of urban environments is enhanced. While the natural level of action of the URS is obviously the urban level, the level of action of the LEC can range from the building scale to the urban level. In this respect, and given the centrality of the energy transition in the European framework, in terms of policies and incentives, the LECs can play an important role by being able to function as driving structures, as they have the capacity to bring together different lines of action, beyond being strictly limited to energy-related issues. For this reason, further research into LECs would be very valuable. A more detailed understanding of their operation would enable the bases of their operation to be established. This understanding could in turn be valuable in promoting UAS, in order to weave a network of UAS that would facilitate an effective implementation of the Urban Agenda for the Basque Country-Bultzatu 2050.

Author Contributions: All authors, I.O.-I., O.G., A.A., C.P. and R.H. have designed the research and analysed the data. I.O.-I. and C.P., wrote the paper. I.O.-I. and A.A. have designed the visualization. O.G. and R.H. were responsible for provision of study materials, supervision and funding acquisition. All authors, I.O.-I., O.G., A.A., C.P. and R.H. reviewed and edited the paper. All authors have read and agreed to the published version of the manuscript.

Funding: This research was funded by the Directorate of territorial planning and urban agenda of the department of territorial planning, housing and transport of the Basque government as part of the financing for CISO30 project, "Action plan for the promotion and implementation of the PCTI Euskadi 2020-2030 in the field of sustainable cities". 
Institutional Review Board Statement: Not applicable.

Informed Consent Statement: Not applicable.

Data Availability Statement: Not applicable.

Conflicts of Interest: The authors declare no conflict of interest. The funders had no role in the design of the study; in the collection, analyses, or interpretation of data; in the writing of the manuscript, or in the decision to publish the results.

\section{References}

1. UN, Department of Economic and Social Affairs, Population Division. The World's Cities in 2018-Data Booklet (ST/ESA/SER.A/417). 2018. Available online: https://www.un.org/en/events/citiesday/assets/pdf/the_worlds_cities_in_ 2018_data_booklet.pdf (accessed on 15 April 2021).

2. UN-HABITAT. New Generation of National Urban Policies. Nairobi. Available online: https://unhabitat.org/new-generation-ofnational-urban-policies-2 (accessed on 8 April 2021).

3. Sustainable Development Goals: Knowledge Platform. Available online: https://sustainabledevelopment.un.org/post2015/ transformingourworld (accessed on 8 April 2021).

4. Filho, W.L.; Tripathi, S.K.; Andrade Guerra, J.B.S.O.D.; Giné-Garriga, R.; Orlovic Lovren, V.; Willats, J. Using the sustainable development goals towards a better understanding of sustainability challenges. Int. J. Sustain. Dev. World Ecol. 2012, 26, 179-190. [CrossRef]

5. Martin, B.R. Twenty challenges for innovation studies. Sci. Public Policy 2016, 43, 432-450. [CrossRef]

6. Zavratnik, V.; Podjed, D.; Trilar, J.; Hlebec, N.; Kos, A.; Stojmenova Duh, E. Sustainable and community-centred development of smart cities and villages. Sustainability. 2020, 12, 3961. [CrossRef]

7. UNSTATS. Sustainable Development Goals Report. 2019. Available online: https://unstats.un.org/sdgs/report/2019 (accessed on 15 April 2021).

8. UNSTATS. The Sustainable Development Goals Report. 2020. Available online: https://unstats.un.org/sdgs/report/2020/ (accessed on 15 April 2021).

9. Easterly, W. The trouble with the sustainable development goals. Curr. Hist. 2015, 114, 322-324. [CrossRef]

10. Bali Swain, R. A critical analysis of the Sustainable Development Goals. In Handbook of Sustainability Science and Research; Leal Filho, W., Ed.; Springer: Cham, Switzerland, 2017; pp. 1-14. [CrossRef]

11. Sprinks, J.; Woods, S.M.; Parkinson, S.; Wehn, U.; Joyce, H.; Ceccaroni, L.; Gharesifard, M. Coordinator perceptions when assessing the impact of citizen science towards sustainable development goals. Sustainability 2021, 13, 2377. [CrossRef]

12. Tremblay, D.; Gowsy, S.; Riffon, O.; Boucher, J.F.; Dubé, S.; Villeneuve, C. A Systemic Approach for Sustainability Implementation Planning at the Local Level by SDG Target Prioritization: The Case of Quebec City. Sustainability 2021, 13, 2520. [CrossRef]

13. Guha, J.; Chakrabarti, B. Achieving the Sustainable Development Goals (SDGs) through decentralisation and the role of local governments: A systematic review. Commonw. J. Local Gov. 2019, 22, 6855. [CrossRef]

14. Martínez-Córdoba, P.J.; Amor-Esteban, V.; Benito, B.; García-Sánchez, I.M. The commitment of Spanish Local Governments to Sustainable Development Goal 11 from a Multivariate Perspective. Sustainability. 2021, 13, 1222. [CrossRef]

15. Moczek, N.; Voigt-Heucke, S.L.; Mortega, K.G.; Fabó Cartas, C.; Knobloch, J. A Self-Assessment of European Citizen Science Projects on Their Contribution to the UN Sustainable Development Goals (SDGs). Sustainability 2021, 13, 1774. [CrossRef]

16. Ajates, R.; Hager, G.; Georgiadis, P.; Coulson, S.; Woods, M.; Hemment, D. Local Action with Global Impact: The Case of the GROW Observatory and the Sustainable Development Goals. Sustainability 2020, 12, 10518. [CrossRef]

17. UNPD. People-centred development: Empowered lives. In Resilient nations; Office of Communications/Partnerships Bureau; UNPD: New York, NY, USA, 2011.

18. Witoelar, E. People-centered cities in a globalizing world: Issues in governance. Transp. Commun. Bull. Asia Pac. 2001, 71, 1-8.

19. Mansuri, G.; Rao, V. Community-based and -driven development: A critical review. World Bank Res. Obs. 2004, 19, 1-39. [CrossRef]

20. Narayan, D. Designing community based development. In Social development notes No. 4; World Bank: Washington, DC, USA, 1995; Available online: http:/ / hdl.handle.net/10986/11662 (accessed on 15 April 2021).

21. Amit, V.; Rapport, N. The Trouble with Community: Anthropological Reflections on Movement, Identity and Collectivity; PLUTO Press: London/Sterling, UK, 2002.

22. Anderson, B. Imagined Communities: Reflections on the Origin and Spread of Nationalism; Verso: London, UK; New York, NY, USA, 2006.

23. Tönnies, F. Community and Society; Harper Torchbooks: New York, NY, USA, 1957.

24. Basque Government. Urban Agenda for the Basque Country-Bultzatu 2050. 2019. Available online: https:/ /www.euskadi.eus / the-bultzatu-2050-urban-agenda/web01-a2lurral/en/ (accessed on 15 April 2021).

25. Regional Innovation Scoreboard. Available online: https://ec.europa.eu/growth/industry/policy/innovation/regional_en (accessed on 21 May 2021). 
26. Doheim, R.M.; Farag, A.A.; Kamel, E. Humanizing Cities Through Car-Free City Development and Transformation; IGI Global: Hershey, PA, USA, 2020. [CrossRef]

27. MERCER. Quality of Living City Ranking. Available online: https://mobilityexchange.mercer.com/insights/quality-of-livingrankings (accessed on 21 May 2021).

28. REScoop.eu. European Federation of Renewable Energy Cooperatives. Available online: https://www.rescoop.eu/network/ (accessed on 15 April 2021).

29. Goiener. Available online: https://www.goiener.com/ (accessed on 15 April 2021).

30. Comunidad Energética Local Lasierra (Álava). Available online: https://comunidadesenergeticas.org/lasierra/ (accessed on 15 April 2021).

31. Ekiola. Available online: https:/ / ekiola.eus/es/ (accessed on 15 April 2021).

32. Elkarbidean, Asociaciones e Inciativas de Viviendas Colaborativas. Available online: https://www.elkarbidean.com/red/ (accessed on 15 April 2021).

33. Koobizitza. Available online: https:/ / www.koobizitza.org (accessed on 15 April 2021).

34. Collantes, J.C.A. El polígono hortícola en el País Vasco como interpretación de las iniciativas territoriales industriales. Investig. Geogr. 2005, 37, 27-45.

35. Centro de Estudios Ambientales. Estrategia Agroalimentaria de Vitoria-Gasteiz. Available online: https://www.vitoria-gasteiz org/wb021/was/contenidoAction.do?idioma=es\&uid=u6d939fe2_1523968eb86_7e24 (accessed on 15 April 2021).

36. Grijalba, O.; Urrutia, N.; Eizaguirre-Iribar, A.; Irulegi, O.; Hernández, R. Impact of the Public Management Model on the Implementation of Urban Regeneration Policies: Evidence of the Case of the Basque Country, Spain. Plan. Pract. Res. 2020, 35, 302-319. [CrossRef]

37. Opengela. Available online: https:/ / opengela.eus/ (accessed on 15 May 2021). 